\title{
How Does a Salesperson Improve Their Performance? The Important Role of Their Customer Smart Response Capability
}

\author{
Diana Aqmala, ${ }^{1 *}$ and Elia Ardyan ${ }^{2}$ \\ ${ }^{1}$ Dian Nuswantoro University, Semarang, Indonesia \\ ${ }^{2}$ Institute of Economic Science (STIE) Surakarta, Surakarta, Indonesia
}

\begin{abstract}
A salesperson is the part of a company who will always meet its customers. A salesperson should have the capability of responding to the customers. This research aims at examining the importance of the salesperson's customer smart response capability for the insurance industry in Indonesia. The respondents in this research are 317 salespeople who work in the insurance industry. This research uses structural equation modeling to process its data. The results of this research show the importance of the customer smart response capability in the insurance industry. This customer smart response capability can improve a salesperson's performance. Additionally, the customer smart response capability mediates the influence of customer sensing on the salesperson's performance and mediates the influence of sales training's effectiveness on the salesperson's performance.
\end{abstract}

Key words: customer smart response capability; salesperson's performance; sales training effectiveness; selling orientation; sensing capability

JEL classification: M31

* Corresponding author’s e-mail: diana.aqmala@gmail.com. 


\section{Introduction}

One of the factors which drives a company's success is its salespeople. The presence of a salesperson is extremely important because he/she is the part of the company that meets directly with the customers. A salesperson will personally communicate the company's product/service values to their customers (Schwepker and Ingram 2016). It is the salesperson who personally understands what their customers want and need. A salesperson is often the only representative of a sales organization seen by the customers. Hence the salesperson's focus is on satisfying the customers' needs (Crosby et al. 1990). A salesperson should try to avoid any customer dissatisfaction with the service they provide (Singh and Ranchhod 2004).

Customer-oriented sales have been increasingly popular in the area of sales management and sales research; organizations are aware that the relational approach to buyer-purchaser interactions is very critical for long-term success (Dwyer et al. 1987; Keillor and Parker 2000). Martin and Bush (2003) explain that customer-oriented sales are designed by companies to improve their customers' satisfaction and service quality. Customer-oriented sales are highly focused on customers, they keep on analyzing the customers' needs, and actively provide solutions for the customers (Saxe and Weitz 1982). Companies should try to identify what makes a salesperson give their best and how he/she can deliver common benefits ( $\mathrm{He}$ et al. 2015). Companies should ensure that their salespeople are fully oriented to their customers. Empirically, this customer orientation has some influence on performance, either corporate performance (Narver and Slater 1990) or the salesperson's performance (Donavan et al. 2004; Singh and Das 2013; Sujan et al. 1994). Another study explains that customer-oriented sales behavior has a positive relationship with the salesperson's performance (Cross et al. 2007; Pousa and Mathieu 2013; Swenson and Herche 1994).

In this research, there are two research gaps. There have been fundamental differences in the results of research into the influence of the selling orientation on the salesperson's performance. Boles et al. (2001) and Knight et al. (2007) find that the selling orientation does not influence a salesperson's performance. Several other researchers find that the selling orientation has a significant influence on a salesperson's performance (Mehrabi et al. 2012; Saxe and Weitz 1982; Wessels 2011). It is possible for the selling orientation to have a positive impact because its focus is a short-term one, rather than having the desire to satisfy the customers and make them loyal to the company (Saxe and Weitz 1982). A salesperson who uses the selling orientation is motivated to deliver the maximum work result to prove their worth to their co-workers or managers (Sujan et al. 1994). In this research, the selling orientation will be tested for its influence on salespeople's customer smart response capability. We want to show how the selling orientation concept is focused on the customers. Secondly, not many studies have discussed the influence of a response capability on a salesperson's performance. Many studies into response capabilities relate to organizational analysis units, where the influence is focused more on corporate performance (Daugherty et al. 1995; DeGroote and Marx 2013; Jayachandran et al. 2004; Liu et al. 2013; Pehrsson 2011 2014). The focus of the response capabil- 
ity in this research is on the company's ability to provide feedback smartly and effectively. This research aims to prove the importance of having a customer smart response capability in the insurance industry in Indonesia.

\section{Literature Review}

\section{Customer Smart Response Capability}

The concept of capability is developed through the RA theory, which was originally suggested by Hunt and Morgan (1995). This theory explains that both visible and invisible resources play essential roles in allowing companies to execute their processes effectively and efficiently, so that they can generate valuable products for their customers. These resources include financial, physical, legal, human, organizational, informational, and relational resources. The capability owned by a salesperson is a part of the human resources, which involves knowledge and ability, which may be unique to each salesperson. This theory is in line with the dynamic capability concept which underlies the importance of competence to keep on adapting to environmental changes (Teece et al. 1997)

One of the concepts of dynamic capability is the customers' response. Customercustomers are the actions taken to respond to market intelligence regarding individual needs of the target customer (Kohli and Jaworski 1990). Organizations should proactively respond to their environmental dynamics (Luu 2017). A company should keep on utilizing any ability it has to respond to changes in its market's demands (Garrett et al. 2009). Any com- pany capable of designing its responsiveness will be able to understand its customers' various demands (Chhetri et al. 2017). As the frontline of an organization, a salesperson should also have the ability to respond. In this research, the ability to respond to customers is called the customer smart response capability. This capability is the ability of the salespeople to provide timely feedback to a customer, by responding to their needs intelligently using the solution sharing principle. With this ability, there is the potential to improve each salesperson's performance.

\section{Selling Orientation}

There have been different opinions about the selling orientation. The selling orientation is the short-term view that success can be achieved by merely selling to customers (Saxe and Weitz 1982). This orientation is closely related to performance achievements or work results, which will serve as the benchmarks for assessing salespeople's performance. The selling orientation is in line with performance orientation, which is defined by Sujan et al. (1994) as a view of how to get a positive evaluation through ability and performance. A salesperson has a high level of individualism in the way he/she obtains a good evaluation from their managers and colleagues. The selling orientation concept, developed by Wessels (2011), is a little bit different from the one proposed by previous researchers, as Wessels researched elite salespeople, i.e., the high-performing ones. The result of the research he conducted proves that the presence of the selling orientation influences the overall work result of a salesperson. The selling orientation here is the idea which leads a salesperson to behave correctly in building, maintaining, and 
monitoring their credibility with customers and members of their industry, as well as their company.

\section{Sales Training Effectiveness}

In life insurance companies, a new salesperson receives several intensive courses which offer many opportunities to connect with different businesses while transmitting professional knowledge, the skills needed to successfully sell insurance, and experience (Durvasula et al. 2004; Fan and Cheng 2006). Sales training is the critical factor for successful personal selling (Pettijohn et al. 2010). Training has particular influence in fulfilling the demand for sales. Most sales managers are aware that sales personnel should be effective problem solvers, needs fulfillers, negotiators, and the builders of positive relationships with their customers (Peterson 1995). Churchill et al. (1993) suggests that sales training is recommended to improve a salesperson's productivity, stimulate communication inside and outside the organization, minimize misunderstandings in the department, help a salesperson to have high moral standards, and reduce sales costs.

\section{Customer Sensing}

Previous researchers have not studied customer sensing very widely. Customer sensing is the continuance of market sensing. Day (1994) suggests that the market sensing ability is an organization's ability to be aware of changes in its market and to make accurate responses in their marketing activities. Customer sensing is a part of marketing sensing, where the marketing sensing involves learning customers' desires, competitors' products and the members of the network's abilities in various ways, and the changes occurring in the marketplace (Day 2002). Sensing is tightly related to the customer's orientation, meaning that a salesperson needs to keep focusing on fulfilling his/her customers' needs through interaction with them, with their final goal being to achieve the customers' satisfaction.

\section{Salesperson Performance}

The behavior of an individual salesperson determines his or her performance. Barker (1999) states that the performance of salespeople can be evaluated using factors that can be controlled by the salesperson him/herself, and can be measured through his/her total volume of sales and the achievement of sales targets. Piercy et al. (1998) explains that every effort made by a salesperson has an impact on their individual performance. For companies, each salesperson is responsible for implementing the marketing strategies set by the company. Therefore, it is important for salespeople to be able to contribute to the company through achieving the desired volume of sales, creating profits for the company, and customers' satisfaction (Baldauf and Cravens 2002). A salesperson's performance is an evaluation of the contribution of that person to achieving the stated organizational goals (Baldauf et al. 2003).

\section{Hypothesis}

\section{Selling Orientation and Customer Smart Response Capability}

In the relevant literature, not many studies have explained the influence of the selling orientation on the customer re- 
sponse capability. The selling orientation occurs when salespeople are mainly involved in sales activities which emphasize obtaining sales (Boles et al. 2001). However, there is another approach, where in doing their sales activities, the salespeople focus on how to understand their customers and try to provide solutions for many of the problems these customers are encountering (Boles et al. 2001; Johnston and Marshall 2005). Those salespeople who keep on offering their products to customers will be in touch with their customers (Williams 1998). It is this intensity which will be used by salespeople to try to understand and respond to their customers. While salespeople are always oriented to sales, they should also adapt to their customers. It is this abilitywhich will make a salesperson more responsive to his or her customers.

H1: The selling orientation has a positive and significant effect on the customer smart response capability.

\section{Customer Smart Response Capability and a Salesperson's Performance}

The customer smart response capability is the salesperson's ability to build a relationship by providing some stimulus to what his/her customers want. The customer smart response capability is formed through such indicators as interactive communication, lateral thinking, and focusing on the message. This customer smart response capability is believed to be able to improve a salesperson's performance. Baldauf and Cravens (2002) elaborate that the salesforce's performance is an evaluation of the contribution made by the salesforce to the organization's goal accom- plishment. A performance-oriented salesperson will probably choose their tasks based on the goals; hence maximizing his/ her success.

Churchill et al. (1985) suggests that a salesperson's performance is an outcome of the implementation of various sales strategies performed by the company. A salesforce's performance can be measured using such indicators as the sales' volume, the growth in the number of customers, and the growth in sales. Sujan et al. (1994) provides the indicators to measure a salesperson's performance, including his/ her contribution to the market share, highprofit product sales, an improved sales volume, new product sales, sales exceeding the set targets and helping the supervisors to reach their goals. The presence of a new ability, including the customer smart response capability,will push a salesperson to work better than ever.

H2: The customer smart response capability has a positive and significant effect on a salesperson's performance.

\section{Customer Sensing and Customer Smart Response Capability}

Saxe and Weitz (1982) state that a customer-oriented salesperson focuses on how they can find what their customers need, how to solve their customers' problems, and to earn their loyalty. The orientation of the salesforce toward their customers, in the research by Fostern and Cadogan (2000), means they achieve superior customers' value, which constitutes a barrier to their competitors trying to penetrate the market, created by the salesforce. To create substantial barriers, resources (the salesforce) with adequate expertise and knowledge are required. The commitment, 
which should be present in a salesperson, is his/her own responsibility, but it forms part of their company's strategic tools that help in creating customers' value and barriers to competitors. The objective of market sensing is to be able to fulfill all of the customers' needs. Fulfilling their customers' needs mean the salespeople should be able to respond to anything they request. Hence, it can be concluded that customer sensing will be able to improve the company's responsiveness to customers (Daugherty et al. 1995; Jayachandran et al. 2004), with the final goal being the fulfillment of the customers' needs.

H3: Customer sensing has a positive and significant effect on the customer smart response capability.

\section{Customer Sensing and Salepeople's Performance}

Customer sensing means a salesperson can find any information available in the market (Day 1994). The information found by the salesperson should be a part of the company's market intelligence (Evans and Schlacter 1985). The salesperson is the actor who will always be in touch with the customers, competitors (Mellow 1989), and markets, hence any information can be readily collected. What should be ensured is that the salesperson is able to provide competitive information (Evans and Schlacter 1985). Frequently the information obtained has a high degree of subjectivity (Negi et al. 2014). When a salesperson can find information and analyze it thoroughly and objectively, then it will result in the greater effectiveness (Negi et al. 2014) and performance of the salesperson.
H4: Customer sensing has a positive and significant effect on a salesperson's performance.

\section{Sales Training's Effectiveness and the Customer Response Capability}

The training and development of a salesperson's skills plays an essential part in generating successful sales (Lynch and Chernatony 2007). Training can improve many of the skills of a salesperson. One of these skills is the ability to listen to customers (Aggarwal et al. 2005; Comer and Drollinger 1999). This ability is not limited to merely listening and understanding what the customers want, it also involves dealing with their complaints (Gilly and Hansen 1992; Johnston and Mehra 2002). The ability to listen means involving the cognitive process and actively feeling, interpreting, evaluating and responding to the verbal and non-verbal messages from both existing and prospective customers (Castleberry and Peterson 1993). It is this ability which will enable a salesperson to quickly respond to the existing or potential customers.

\section{H5: Sales training's effectiveness has a positive and significant effect on the customer re- sponse capability.}

\section{Sales Training's Effectiveness and Salesperson's Performance}

In essence, sales training results in the improved performance of the sales staff. The company invests in training to improve their profitability, productivity and sales (Wilson et al. 2002). Previous research shows that sales training can improve a salesperson's performance (Cheng 2014). Sales training significantly contributes to 
the salesforce's knowledge, skills and performance levels (Piercy et al. 1998). To improve a salesperson's performance, companies teach their salespeople the knowledge they need to know about the company employing them and the products they make, sales skills, and how to communicate with customers (McQuiston and Walters 1989). They are then assessed to determine whether the training has been effective or not (Attia and Honeycutt 2012). Greater product knowledge increases the sales staffs' understanding of how good the product is, and if it matches the customers' needs and expectations (Steward et al. 2009). Knowledge about the product will result in improved performance by the salesperson (Sangtani and Murshed 2017).

H6: Sales training's effectiveness has a positive and significant effect on a salesperson's performance

\section{The Customer Smart Response Capability Mediates the Influence of Customer Sensing on a Salesperson's Performance}

In this research, we argue that customer sensing does not necessarily have a direct influence on performance. Daugherty et al. (1995) explains that one of the factors which drives responsiveness is information. This information is obtained when the salesperson senses the customers. The knowledge of the presence of a customer will improve the performance of the salesperson, because he/she can better understand the customer when they meet, which leads to an improvement in their sales results. Sometimes, the information obtained by a salesperson is more subjective (Negi et al. 2014); hence, it does not directly influence the salesperson's performance. This study tries to analyze how the information from customers will influence the salesperson's ability to respond to the customer, which eventually will influence the salesperson's performance.

H7: The customer smart response capability can mediate the influence of sensing the presence of a customer on a salesperson's performance

\section{The Customer Smart Response Capability Mediates the Influence of Sales Training's Effectiveness on a Salesperson's Performance}

Several studies explain the direct influence of the training organized by a company on their salespeople's performance (Cheng 2014; Wilson et al. 2002). In this study, we try to analyze the indirect impact of the influence of sales training's effectiveness on a salesperson's performance. Training will influence a salesperson's ability to respond to customers. During the training, they will learn how to understand and respond to customers correctly. To respond means to be able to handle complaints (Davidow 2000; Yavas et al.and004), to be able to identify some fundamental problems (Bonney and Wolliams 2009), provide the right solutions (Nguyen et al. 2012), and many more things. Any customer receiving a fast and proper response to their problem will be satisfied. The literature also explains that responding to customers' complaints will create customer satisfaction and loyalty (Smith et al. 1999). Customer satisfaction and loyalty will have a direct influence on a salesperson's performance. Hence, it can be concluded that sales training will effectively influence the customer response capability, which, in 
Figure 1. Empirical Research Method

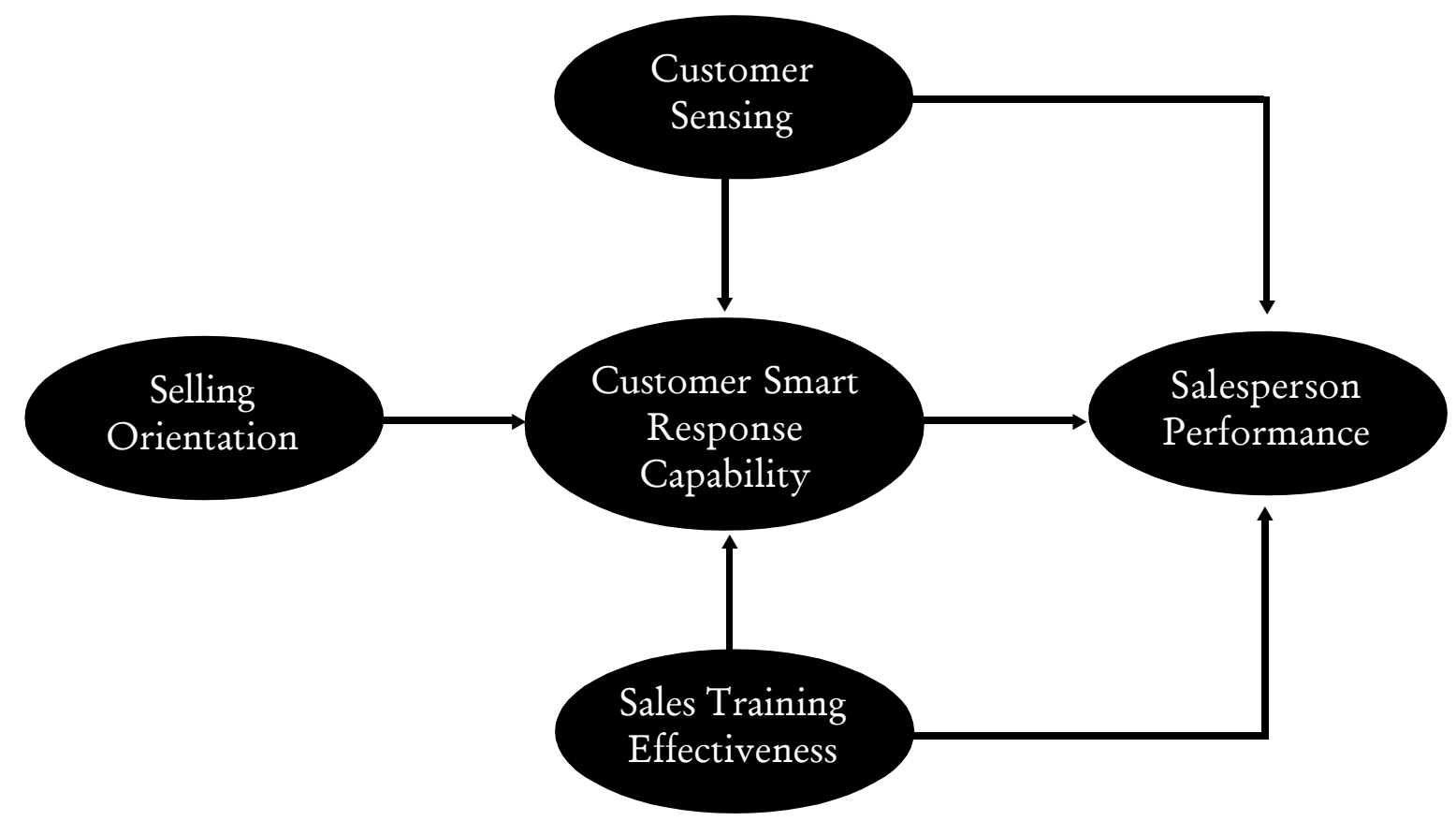

turn will influence the salesperson's performance. Figure 1 shows the empirical model of this research.

H8: The customer smart response capability can mediate the influence of sales training's effectiveness on a salesperson's performance

\section{Research Method}

\section{Population and Sample}

The insurance companies forming the sample in this research are selected using the purposive sampling method, and they are all members of the Indonesian Life Insurance Association and come under the Financial Services Authorities. These companies, which comprise the sample, are also classified as the best insurance companies by Investor magazine. This research was conducted in Central Java, and includes some large cities, namely: Semarang, $\mathrm{Ku}-$ dus, Yogyakarta, Solo, Jepara, and Salatiga. The data are collected by distributing questionnaires to life insurance salespeople. The questionnaires were sent out to 700 potential respondents from July 2016 to February 2017, and 317 of them were returned (a response rate of $45.29 \%$ ). Table 1 shows the profile of the respondents in this study.

\section{Measurement}

In this research, five indicators are used, namely the selling orientation, customer sensing, sales training's effectiveness, the customer smart response capability, and the salesperson's performance. Every variable has several indicators. Every question item built into this study uses a one to seven measurement scale, where one is the 
Table 1. Profile of Respondents

\begin{tabular}{|c|c|c|c|}
\hline Item & Description & $\begin{array}{c}\text { Frequency } \\
\mathbf{n = 3 1 7}\end{array}$ & $\begin{array}{c}\text { Percentage } \\
(\%)\end{array}$ \\
\hline \multirow{2}{*}{ Sex } & Male & 111 & 35.02 \\
\hline & Female & 206 & 64.98 \\
\hline \multirow{5}{*}{ Age } & $<26$ years old & 42 & 13.25 \\
\hline & $26-35$ years old & 97 & 30.60 \\
\hline & $36-45$ years old & 76 & 23.97 \\
\hline & 46 - 55 years old & 72 & 22.72 \\
\hline & $>55$ years old & 30 & 9.46 \\
\hline \multirow{5}{*}{ Last Education } & SMA & 106 & 33.44 \\
\hline & $\mathrm{D} 1 / \mathrm{D} 2 / \mathrm{D} 3$ & 49 & 15.46 \\
\hline & $\mathrm{D} 4 / \mathrm{S} 1$ & 123 & 38.80 \\
\hline & $\mathrm{S} 1 / \mathrm{S} 2$ & 17 & 5.36 \\
\hline & Others & 22 & 6.94 \\
\hline \multirow{5}{*}{ Working for } & 1 to 2 years & 91 & 28.71 \\
\hline & $>2$ to 3 years & 57 & 17.98 \\
\hline & $>3$ to 4 years & 23 & 7.26 \\
\hline & $>4$ to 5 years & 37 & 11.67 \\
\hline & $>5$ years & 109 & 34.38 \\
\hline \multirow{5}{*}{ Bonus (in Rupiah) } & $\leq 1,000,000$ & 50 & 15.77 \\
\hline & $\overline{1,000,001}$ to $2,000,000$ & 68 & 12.45 \\
\hline & $2,000,001$ to $4,000,000$ & 98 & 30.91 \\
\hline & $4,000,001$ to $8,000,000$ & 67 & 21.14 \\
\hline & $>8,000,000$ & 34 & 10.73 \\
\hline
\end{tabular}

strongly disagree answer and seven the strongly agree answer. Below are the indicators in this study:

- The indicators for the selling orientation are adopted from Wessels (2011) and Wachner et al. (2009), i.e., keep on supplying information to customers, exploring every way to obtain new buyers, and driving purchasing continuously.

- The indicators of customer sensing are adopted from Menguc et al. (2013) and Pavlovich and Krahnke (2012), such as the ease of obtaining information from customers, fast access to the customers' data, analysis of the customers' satisfaction with the company's product and learning about the environment.

- The indicators of sales training's effectiveness are adopted from Wagonhurst (2002), and include a thorough understanding of the product, understanding of the product's utilization, understanding of the product's superiority, and understanding how to offer the product. 
- The indicators for the customer smart response capability are adopted from Jayachandran et al. (2004), namely the responsiveness to the customers' needs, communicating smartly, and sharing solutions to the customers' problems.

- The indicators for the salesperson's performance are adopted from Pettijohn et al. (2007), i.e., improved sales volume, improved number of new customers, increased sales incentives, target accomplishment within the set deadline, and keeping existing customers.

\section{Data Analysis}

This study uses structural equation modeling for analyzing its data. The tool used as an aid in processing the data is AMOS version 21. This research also analyzes any mediating influence. This study uses a Sobel test to measure the mediating influence.

\section{Results}

\section{Measurement Model}

This study tests for its validity and reliability. This test is done to prove the validity and reliability of the question items in the questionnaire. The validity test in this study uses factor loading and Average Variance Extracted (AVE). The required factor loading and AVE values are $>0.5$ (Hair et al. 2010). Table 2 shows that the factor loading and AVE values are all above those required. Thus it can be concluded that the proposed question items have validity. The reliability test in this study uses Composite Reliability (CR), where its cut off value should be above 0.6 (Hair et al. 2010). Table 2 indicates that all the CR val- ues are above the predetermined one. Hence it can be concluded that the proposed question items are reliable.

\section{Structural Model}

The data are analyzed using AMOS 21 statistic software for the full structural equation model. Our analysis's structural model shows a good model acceptance level, therefore it can be concluded that some indices such as $\chi^{2}=152.029$; probability significance $=0.287 ; \mathrm{Cmin} / \mathrm{DF}=$ 1,063; $\mathrm{GFI}=0.950 ; \mathrm{AGFI}=0.934$; $\mathrm{TLI}=$ 0.997; CFI $=0.998$; $\mathrm{RMSEA}=0.014$, hence our model fits the expected population.

Table 3 shows the hypotheses' testing results. Based on the test results, it is found that seven hypotheses are confirmed and one hypothesis is rejected. We find a positive relationship between the selling orientation and the customer smart response capability $(\beta=0.272 ; \mathrm{p}<0.05)$, indicating that an increased selling orientation will result in an increased customer smart response capability, providing support for Hypothesis 1 . We also find results which support Hypothesis $2(\beta=0.536$; $\mathrm{p}<0.05)$; Hypothesis $3(\beta=0.379 ; \mathrm{p}<$ 0.05); Hypothesis $4(\beta=0.255 ; \mathrm{p}<0,05)$ and Hypothesis 5 ( $\beta=0.194 ; \mathrm{p}<0,05)$. In this study, we find that sales training's effectiveness cannot improve the customer smart response capability $(\beta=0.255$; $\mathrm{p}<$ $0.05)$; hence this result does not support Hypothesis 6.

Table 3 also indicates the influence of the customer smart response capability as a mediating variable. We find that the customer smart response capability can mediate the influence of the customer-sensing capability on a salesperson's performance 
Table 2. Loading of the item measurement, Composite Reliability (CR) and AVE

\begin{tabular}{|c|c|}
\hline Variable\& Indicator & $\begin{array}{l}\text { Factor } \\
\text { Loading }\end{array}$ \\
\hline $\begin{array}{l}\text { Selling Orientation }(\mathrm{AVE}=0.683 ; \mathrm{CR}=0.886) \\
\text { - Keep on supplying information to customers } \\
\text { - Exploring every way to obtain new buyers } \\
\text { - } \text { Driving purchasing continuously }\end{array}$ & $\begin{array}{l}0.82 \\
0.84 \\
0.82\end{array}$ \\
\hline $\begin{array}{l}\text { Customer Sensing (AVE }=0.753 ; \mathrm{CR}=0.924) \\
\text { - The ease of obtaining information from customers } \\
\text { - Fast access to the customers' data } \\
\text { - Analysis of the customers' satisfaction with the company's product } \\
\text { - Learning about the environment }\end{array}$ & $\begin{array}{l}0.88 \\
0.87 \\
0.85 \\
0.87\end{array}$ \\
\hline $\begin{array}{l}\text { Sales Training Effectiveness (AVE }=0.663 ; \mathrm{CR}=0.887 \text { ) } \\
\text { - Thorough understanding of the product } \\
\text { - Understanding of the product's utilization } \\
\text { - Understanding of the product's superiority } \\
\text { - Understanding of how to offer the product }\end{array}$ & $\begin{array}{l}0.86 \\
0.86 \\
0.75 \\
0.78\end{array}$ \\
\hline $\begin{array}{l}\text { Customer Smart Response Capability (AVE }=0.635 ; \mathrm{CR}=0.839) \\
\text { - Responsiveness to the customers' needs } \\
\text { - Communicating smartly } \\
\text { - Sharing solutions to the customers' problems. }\end{array}$ & $\begin{array}{l}0.80 \\
0.81 \\
0.78\end{array}$ \\
\hline $\begin{array}{l}\text { Salesperson performance }(\mathrm{AVE}=0.662 ; \mathrm{CR}=0.887) \\
\text { - Improved sales volume } \\
\text { - Improved number of new customers } \\
\text { - Increased sales incentives } \\
\text { - Target accomplishment within the set deadline } \\
\text { - Keeping existing customers }\end{array}$ & $\begin{array}{l}0.84 \\
0.74 \\
0.83 \\
0.84 \\
0.75\end{array}$ \\
\hline
\end{tabular}

\section{Table 3. Hypotheses Testing Results}

\begin{tabular}{|c|c|c|c|}
\hline Hypothesis & $\beta$ & $\mathrm{p}$ & Result \\
\hline $\begin{array}{l}\text { H1: Selling orientation } \rightarrow \text { Customer smart } \\
\text { response capability }\end{array}$ & 0.272 & 0.000 & Supported \\
\hline $\begin{array}{l}\text { H2: Customer smart response capability } \rightarrow \\
\text { Salesperson's performance }\end{array}$ & 0.536 & 0.000 & Supported \\
\hline $\begin{array}{l}\text { H3: Customer sensing } \rightarrow \text { Customer smart } \\
\text { response capability }\end{array}$ & 0.379 & 0.000 & Supported \\
\hline $\begin{array}{l}\text { H4: Customer sensing } \rightarrow \text { Salesperson's } \\
\text { performance }\end{array}$ & 0.255 & 0.001 & Supported \\
\hline
\end{tabular}




\section{Table 3. Continued}

\begin{tabular}{lccc}
\hline \multicolumn{1}{c}{ Hypothesis } & $\boldsymbol{\beta}$ & $\mathrm{p}$ & Result \\
\hline $\begin{array}{l}\text { H5: Sales training's effectiveness } \rightarrow \\
\text { Customer smart response capability }\end{array}$ & 0.194 & 0.002 & Supported \\
$\begin{array}{l}\text { H6: Sales training's effectiveness } \rightarrow \\
\text { Salesperson's performance }\end{array}$ & 0.136 & 0.056 & Not Supported \\
\hline \multicolumn{1}{c}{ Hypothesis } & $\begin{array}{c}\text { Sobel } \\
\text { Test }\end{array}$ & $\mathrm{p}$ & Result \\
\hline $\begin{array}{l}\text { H7: Customer sensing } \rightarrow \text { Customer smart } \\
\text { response capability } \rightarrow \text { Salesperson's } \\
\text { performance }\end{array}$ & 2.846 & 0.002 & Supported \\
H8: Sales training's effectiveness $\rightarrow$ \\
$\begin{array}{l}\text { Customer smart response capability } \rightarrow \\
\text { Salesperson's performance }\end{array}$ & 1.709 & 0.043 & Supported \\
\hline
\end{tabular}

(Sobel test $=2.846 ; \mathrm{p}<0.05$ ), providing support for Hypothesis 7 . We also find that the customer smart response capability can mediate the influence of sales training's effectiveness on a salesperson's performance (Sobel test $=1.709 ; \mathrm{p}<0.05$ ), hence this research result supports Hypothesis 8.

\section{Discussion}

The capability to respond to a customer is an essential ability in any industrial sector. In this study, a salesperson should have the ability to respond to a customer's requests. It means the salesperson should always be responsive to the customers' needs, is able communicate promptly and clearly, and share solutions with the customer. In this study, the customer smart response capability is driven by the selling orientation, the customer sensing ability, and the sales training's effectiveness. This research also finds the critical role played by the customer smart response capability, which can mediate the influence of customer sensing and sales training's effectiveness on a salesperson's performance.

In the insurance industry in Indonesia, the selling orientation can improve the customer smart response capability. It is quite often that the selling orientation's concept is viewed negatively by customers, because this concept constitutes the salesperson's behavior, which customers find too aggressive (Guenzi et al. 2016). DelVecchio et al. (2003) also explains that the nature of this selling orientation is meant to be a manipulation tactic. However, in this research, the selling orientation causes a salesperson to meet with their customers consistently. The meetings happen not just when the salesperson offers their insurance products; rather, the salesperson will frequently meet with the customers when they make claims. This meeting intensity enables the salesperson to maintain his/her integrity. It changes what was initially 
meant merely to manipulate into a tactic which always put the customers first. The salesperson will try to improve his/her responsiveness, to satisfy their customers. Therefore, the selling orientation will positively result in an improved customer smart response capability.

The customer smart response capability can improve a salesperson's performance. Responding to customers is part of the customer orientation. Customer orientation refers to the level at which a salesperson tries to help their customers make decisions which will solve their problems and fulfill their needs (Cherry and Fraedrich 2002). Any employee who is oriented toward customers will try harder to understand their needs and provide information about the products and services which suit the customers, hence facilitating the customers' analysis and selection, and improving their satisfaction (Jaramillo et al. 2007).

Customer sensing can improve the customer smart response capability. The research conducted by Jayachandran et al. (2004) also finds that customer knowledge has some influence on the customer response capability. Customer knowledge will improve the salesperson's ability to identify the customer's needs and isolate any potential market segment. It increases the number of employees who are adept at responding to customers. In this research, customer knowledge is shaped by knowledge gained from the customer, knowledge by the customer, and knowledge on the customer. This knowledge will improve the accuracy in identifying the customers' needs. This accuracy in identifying what the customers need and want depends on the knowledge owned by the salesforce. The better the salesperson's cus- tomer knowledge is, the better the customer smart response capability will be.

This study finds that customer sensing can influence a salesperson's performance improvement. Buyers want a salesperson who can communicate well, understand what they need, solve their problems, and satisfy them. In order to fulfill these customers' demands, it is necessary to know customers, through the knowledge coming from customers, and the knowledge about customers. Any salesperson with this sort of knowledge will be able to win over these customers, and this is directly proportional to the salesperson's performance achievement. The study held by Menguc et al. (2013) finds that the higher the salesperson's customer knowledge is, the greater is the improvement in their performance. The performance measures used by Menguc et al. (2013) are the customer relations performance and financial performance.

Sales training's effectiveness can improve the customer smart response capability. Sales training is a part of the selling orientation because any salesperson with a learning orientation will be driven to develop their ability to the point where this salesperson will be able to improve their understanding of their sales environment and their insight into its sales strategy. A person's learning orientation can be measured through the amount of training attended, and the experience possessed by that person. Hence the salesforce will learn from the experience they collectively have, and additionally, they will always want to learn something new about their customers (Sujan et al. 1994).

This research result shows that sales training's effectiveness has no significant 
impact on the performance of a salesperson. This finding differs from the previous research (Cheng 2014). The training attended by salespeople does not directly improve their performance. In this research, training will have some influence on the customer smart response capability, which eventually will improve a salesperson's performance. It is also possible that there are several causes that make sales training's effectiveness fail to significantly influence the sales staffs' performance in the insurance industry in Indonesia. Firstly, training has a greater tendency to make a salesperson motivated and enthusiastic (Douglas 2002). Motivation and enthusiasm do not necessarily influence the performance of a salesperson directly. Secondly, the coaching concept is a better method to use for the insurance industry.

\section{Implication to Knowledge}

There are some theoretical implications in this research. Firstly, SO is usually deemed as a 'hard sales' form, related to manipulative tactics aimed at maximizing the seller's interest, even at the buyer's cost (DelVecchio et al. 2003). Frequently, a sales-oriented salesperson fails to respond to their customers in an appropriate manner. This is because this salesperson's focus is only on him/herself. However, this research found that the selling orientation can improve the customer smart response capability. Secondly, in many studies, it is suggested that the influence of customer sensing on the responding capability and performance is analyzed at the organizational analysis unit, rather than at an individual level. This research found that the sensing capability has a significant influence on the customer smart response capability and improved the salesperson's performance. Thirdly, the customer smart response capability has become an important tool. This research's results show that the customer smart response capability can be a central capability which mediates the influence of customer sensing on the salesperson's performance and the influence of the effectiveness of sales training on a salesperson's performance.

\section{Managerial Implication}

There are several managerial implications. Firstly, companies should mentor their employees to enable them to have the capability to respond to their customer promptly, and to improve their performance. Mentoring is more than just training because this study finds that training cannot improve a salesperson's performance. The mentoring here means to assist the employees until they succeed at certain levels. Secondly, the customer smart response capability will be highly helpful to the salespeople's performance. Each salesperson should be responsive to the customers' needs, be able to communicate promptly and clearly, and share solutions.

\section{Limitation and Future Research}

The limitation in this research is that it has not distinguished between the different types of insurance, because the data were obtained from several insurance companies which have different insurance products. From this research, some agendas can be considered for future research, i.e., further research could be conducted into the existing insurance types, in order to obtain more specific results. Future re- 
searchers can consider the use of other antecedent variables, which potentially can improve a salesperson's performance, such as the salesperson's creativity (Miao and Wang 2016). Future researchers can also include salespeople who need high levels of involvement with their customers, such as those who sell multi-level marketing, credit cards and savings products for future investment.

\section{References}

Aggarwal, P., S. B. Castleberry, R. Ridnour, and C. D. Shepherd. 2005. Salespeople's empathy and listening: impact on relationship outcomes. Journal of Marketing Theory and Practice 13 (3): 16-31.

Attia, A. M., and E. D. Honeycutt. 2012. Measuring sales training's effectiveness at the behavior and results levels using self- and supervisor evaluations. Marketing Intelligence and Planning 30 (3): 324-338.

Baldauf, A., and D. W. Cravens. 2002. The effect of moderators on the salesperson's behavior performance and salesperson's outcome performance and sales organization's effectiveness relationships. European Journal of Marketing 36 (11/12): 1367-1388.

Baldauf, A., K. S. Cravens, and G. Binder. 2003. Performance consequences of brand equity management: Evidence from organizations in the value chain. Journal of Product and Brand Management 12 (4): 220-236.

Barker, T. A. 1999. Benchmark of successful salesperson's performance. Canadian Journal of Administrative Sciences 16 (2): 95-104.

Boles, J. S., B. J. Babin, and T. G. Brashear. 2001. An examination of the relationships between retail work environments, the salesperson's selling orientation customer orientation and job performance. Journal of Marketing Theory and Practice 9 (3): 1-13.

Bonney, F. L., and B. C. Wolliams. 2009. From products to solutions: The role of salesperson's opportunity recognition. European Journal of Marketing 43 (7/8): 1032-1052.

Castleberry, S. B., and R. A. Peterson. 1993. Effective interpersonal listening and personal selling. Journal of Personal Selling and Sales Management 13 (Winter): 35-49.

Cheng, C.-Y. 2014. A longitudinal study of newcomer's job embeddedness and sales outcomes for life insurance salespersons. Journal of Business Research 67: 1430-1438.

Cherry, J., and J. Fraedrich. 2002. Perceived risk, moral philosophy and marketing ethics: mediating influences on sales managers' ethical decision-making. Journal of Business Research 55 (12): 951-962.

Chhetri, P., B. Kam, K. H. Lau, B. Corbitt, and F. Cheong. 2017. Improving service responsiveness and delivery efficiency of retail networks: A case study of Melbourne. International Journal of Retail and Distribution Management 45 (3): 271-291.

Churchill, G. A., N. M. Ford, S. W. Hartley, and O. C. Walker. 1985. The determinants of a salesperson's performance: A meta-analysis. Journal of Marketing Research 22 (2): 103-118.

Churchill, G. A., N. M. Ford, and O. C. Walker. 1993. Sales Force Management. Homewood, IL.: R. D. Irwin. 
Comer, L. B., and T. Drollinger. 1999. Active empathetic listening and selling success: a conceptual framework. Journal of Personal Selling and Sales Management 19 (1): 15-29.

Crosby, L. A., K. R. Evans, and D. Cowles. 1990. Relationship quality in services selling: An interpersonal influence perspective. Journal of Marketing 54 (July): 68-81. doi: https://doi.org/ 10.1177\%2F002224299005400306.

Cross, M. E., T. G. Brashear, E. E. Rigdon, and D. N. Bellenger. 2007. Customer orientation and salesperson's performance. European Journal of Marketing 41 (7/8): 821-835.

Daugherty, P. J., A. E. Ellinger, and D. S. Rogers. 1995. Information accessibility: Customer responsiveness and enhanced performance. International Journal of Physical Distribution and Logistics Management 25 (1): 4-17. doi: 10.1108/09600039510080117.

Davidow, M. 2000. The bottom line impact of organizational responses to customer complaints. Journal of Hospitality and Tourism Research 24 (4): 473-490.

Day, G. S. 1994. The capabilities of market-driven organizations. Journal of Marketing 58 (October): 37-52. doi: 10.2307/1251915.

Day, G. S. 2002. Managing the market learning process. Journal of Business and Industrial Marketing 17 (4): 2002.

DeGroote, S. E., and T. G. Marx. 2013. The impact of IT on supply chain agility and firm performance: An empirical investigation. International Journal of Information Management 33: 909-916.

DelVecchio, S. K., J. E. Zemanek, R. P. McIntyre, and R. P. Claxton. 2003. Buyers' perceptions of salesperson's tactical approaches. Journal of Personal Selling and Sales Management 23 (1): 39-49.

Donavan, D. T., T. J. Brown, and J. C. Mowen. 2004. Internal benefits of service-worker customer orientation: job satisfaction, commitment, and organizational citizenship behaviors. Journal of Marketing 68: 128-146.

Douglas, M. 2002. Selling peak performance. Industrial and Commercial Training 34 (5): 188-190.

Durvasula, S., S. Lysonski, C. Mehta, and B. P. Tang. 2004. Forging relationships with services: The antecedents that have an impact on behavioral outcomes in the life insurance industry. Journal of Financial Services Marketing 8 (3): 314-326.

Dwyer, F. R., P. H. Schurr, and S. Oh. 1987. Developing buyer-seller relationship. Journal of Marketing 51 (2): 11-87.

Evans, K., and J. Schlacter. 1985. The role of Sales Managers and Salespeople in a Marketing Information System. Journal of Personal Selling and Sales Management 5 (3): 49-58.

Fan, C. K., and C. L. Cheng. 2006. A study to identify the training needs of life insurance sales representatives in Taiwan using the Delphi approach. International Journal of Training and Development 10 (3): 212-226.

Fostern, B. D., and J. W. Cadogan. 2000. Relationship selling and customer loyalty: an empirical investigation. Marketing Intelligence and Planning 18 (4): 185-199.

Garrett, R. P., J. Covin, and D. P. Slevin. 2009. Market responsiveness, top management risktaking, and the role of strategic learning as determinants of market pioneering. Journal of Business Research 62 (8): 782-788. 
Gilly, M. C., and R. W. Hansen. 1992. Consumer complaint handling as a strategic marketing tool. The Journal of Product and Brand Management 1 (3): 5-16.

Guenzi, P., L. M. De Luca, and R. Spiro. 2016. The combined effect of customer perceptions about a salesperson's adaptive selling and selling orientation on customers' trust in the salesperson: a contingency perspective. Journal of Business and Industrial Marketing 31 (4): 553564.

Hair, J. F., W. C. Black, B. J. Babin, and R. E. Anderson. 2010. Multivariate Data Analysis (7th ed.). New York: A Global Perspective.

He, H., W. Wang, W. Zhu, and L. C. Harris. 2015. Service workers' job performance: the roles of personality traits, organizational identification, and customer orientation. European Journal of Marketing 49 (11/12): 1751-1776.

Hunt, S. D., and R. M. Morgan. 1995. The comparative advantage theory of competition. Journal of Marketing 59 (2): 1-15.

Jaramillo, F., D. M. Ladik, G. W. Marshall, and J. P. Mulki. 2007. A meta-analysis of the relationship between sales orientation-customer orientation (SOCO) and a salesperson's job performance. Journal of Business and Industrial Marketing 22 (5): 302-310.

Jayachandran, S., K. Hewett, and P. Kaufman. 2004. Customer response capability in a sense and respond era: The role of customer knowledge process. Journal of the Academy of Marketing Science 32 (3): 219-233.

Johnston, M. W., and G. W. Marshall. 2005. Relationship Selling and Sales Management (2 ${ }^{\text {nd }}$ ed.). Boston, MA: McGraw-Hill/Irwin.

Johnston, R., \& Mehra, S. (2002). Best-practice complaint management. Academy of Management Executive, 16(4), 145-154.

Keillor, D. B., and R. S. Parker. 2000. Relationship-oriented characteristics and an individual salesperson's performance. Journal of Business and Industrial Marketing 15 (1): 7-22.

Knight, D. K., H-J. Kim, and C. Crutsinger. 2007. Examining the effect of role stress on customer orientation and job performance of retail salespeople. Journal of Business and Industrial Marketing 35 (5): 381-392.

Kohli, A. K., and B. J. Jaworski. 1990. Market orientation: The construct,research propositions, and managerial implications. Journal of Marketing 54 (2): 1-18.

Liu, H., W. Ke, K. K. Wei, and Z. Hua. 2013. The impact of IT capabilities on firm performance: The mediating roles of absorptive capacity and supply chain agility. Decision Support System 54: 1452-1462.

Luu, T. T. 2017. Market responsiveness: antecedents and the moderating role of external supply chain integration. Journal of Business and Industrial Marketing 32 (1): 30-45.

Lynch, J., and L. D. Chernatony. 2007. Winning hearts and minds: Business-to-business branding and the role of the salesperson. Journal of Marketing Management 23 (1-2): 123-135.

Martin, C. A., and A. J. Bush. 2003. The potential influence of organizational and personal variables on customer-oriented selling. Journal of Business and Industrial Marketing 18 (2): 114132.

McQuiston, D. H., and R. G. Walters. 1989. The evaluative criteria of industrial buyers: Implications for sales training. Journal of Business and Industrial Marketing 4 (2): 65-75. 
Mehrabi, J., K. Noorbakhash, M. Shoja, and K. Mohammad. 2012. Impact of customer orientation and sales orientation on sales performance in international market of Bilehsavar country. International Journal of Business and Social Science 3 (17): 216-222.

Mellow, C. 1989. The best source of competitive intelligence. Sales and Marketing Management 141: 24-29.

Menguc, B., S. Auh, and A. Uslu. 2013. Customer knowledge creation capability and performance in sales teams. Journal of the Academy of Marketing Science 41 (1): 19-39.

Miao, C. F., and G. Wang. 2016. The differential effects of functional vis-à-vis relational customer orientation on a salesperson's creativity. Journal of Business Research 69 (12): 6021-6030.

Narver, J. C., and S. F. Slater. 1990. The effect of a market orientation on business profitability. Journal of Marketing 54 (4): 20-35.

Negi, D. S., S. Jain, and V. Sharma. 2014. Marketing intelligence of sales force and sales effectiveness. Pacific Business Review International 6 (10): 16-21.

Nguyen, D. T., J. R. McColl-Kennedy, and T. S. Dagger. 2012. Matching service recovery solutions to customer recovery preferences. European Journal of Marketing 46 (9): 1171-1194.

Pavlovich, K., and K. Krahnke. 2012. Empathy, connectedness, and organization. Journal of Business Ethics 105 (1): 131-137.

Pehrsson, A. 2011. Firms' customer responsiveness: relationships with competition, market growth, and performance. Journal of Strategic and Management 4 (4): 347-364. doi: 10.1108/ 17554251111181007.

Pehrsson, A. 2014. Firms' customer responsiveness and performance: The moderating roles of dyadic competition and firm's age. Journal of Business and Industrial Marketing 29 (1): 34-44. doi: 10.1108/JBIM-01-2011-0004.

Peterson, R. A. 1995. Relationship marketing and the consumer. Journal of the Academy of Marketing Science 23 (4): 278-281.

Pettijohn, C. E., L. S. Pettijohn, and A. J. Taylor. 2007. Does the salesperson's perception of the importance of sales skills improve sales performance, customer orientation, job satisfaction, and organizational commitment, and reduce turnover? Journal of Personal Selling and Sales Management 27 (1): 75-88.

Pettijohn, C. E., E. J. Rozell, and A. Newman. 2010. The relationship between emotional intelligence and customer orientation for pharmaceutical salespeople: A UK perspective. International Journal of Pharmaceutical and Healthcare Marketing 4 (1): 21-39.

Piercy, N. F., D. W. Cravens, and N. A. Morgan. 1998. Salesforce performance and behaviorbased management processes in business to business sales organizations. European Journal of Marketing 32 (1/2): 79-100.

Pousa, C., and A. Mathieu. 2013. Boosting customer orientation through coaching: A Canadian study. International Journal of Banking Marketing 32 (1): 60-81.

Sangtani, V., and F. Murshed. 2017. Product knowledge and a salesperson's performance: Rethinking the role of optimism. Marketing Intelligence and Planning. doi: https://doi.org/ 10.1108/MIP-11-2016-0199.

Saxe, R., and B. A. Weitz. 1982. The SOCO scale: A measure of the customers' orientation of salespeople. Journal of Marketing Research 19 (3): 343-351. 
Schwepker, C. H., and T. N. Ingram. 2016. Ethical leadership in the salesforce: Effects on a salesperson's customer orientation, commitment to customer value, and job stress. Journal of Business and Industrial Marketing 31 (7): 914-927.

Singh, R., and G. Das. 2013. The impact of job satisfaction, adaptive selling behaviors, and customer orientation on a salesperson's performance: Exploring the moderating role of selling experience. Journal of Business and Industrial Marketing 28 (7): 554-564.

Singh, S., and A. Ranchhod. 2004. Market orientation and customer satisfaction: Evidence from the British machine tool industry. Industrial Marketing Management, 33(2), 135-144.

Smith, A. K., R. N. Bolton, and J. Wagner. 1999. A model of customer satisfaction with service encounters involving failure and recovery. Journal of Marketing Research 36: 356-372.

Steward, M. D., M. D. Hutt, B. A. Walker, and A. Kumar. 2009. Role identity and attributions of high-performing salespeople. Journal of Business and Industrial Marketing 24 (7): 463-473.

Sujan, H., B. A. Weitz, and N. Kumar. 1994. Learning orientation, working smart, and effective selling. Journal of Marketing 58: 39-52.

Swenson, M. J., and J. Herche. 1994. Social values and salespeople's performance: and empirical examination. Journal of Academy of Marketing Science 22 (3): 283-289.

Teece, D. J., G. Pisano, and A. Shuen. 1997. Dynamic capabilities and strategic management. Strategic Management Journal 18 (7): 509-533.

Wachner, T., C. R. Plouffe, and Y. Gregorie. 2009. SOCO's impact on individual sales performance: The integration of selling skills as a missing link. Journal of Industrial Marketing Management 38 (1): 32-44.

Wagonhurst, C. 2002. Effective training programs. Journal of Research Administration 33 (2/3): 77-81.

Wessels, G. F. 2011. Salespeople's Selling Orientation: Reconceptualization, Measurement, and Validity Assessment. University of Arizona.

Williams, M. R. 1998. The influence of a salesperson's customer orientation on buyer-seller relationship development. Journal of Business and Industrial Marketing 13 (3): 271-289.

Wilson, P., D. Strutton, and M. T. Farris. 2002. Investigating the perceptual aspect of sales training. Journal of Personal Selling and Sales Management 22 (2): 77-86.

Yavas, U., O. M. Karatepe, E. Babakus, T. Avci. 2004. Customer complaints and organizational responses: A study of hotel guests in Northern Cyprus. Journal of Hospitality and Leisure Marketing 11 (2-3): 31-46. doi: 10.1300/J150v11n02_04 